\title{
THE EFFECT OF MEASUREMENT ERROR OF THE GAS METER TO THE CALCULATION OF GAS CONSUMPTION
}

\author{
Zlatko Tonković, Damir Fekete, Pero Raos
}

Preliminary notes

Natural gas is one of the most important energy sources of the modern age. Gas network delivers gas from the exploitation site to the end user. Flow meters are used to measure quantity of gas supplied and they must meet firm standards regarding measurement. G4 gas meters used in housholds are investigated in test laboratory. Experimental results are analyzed in this paper and conclusions about correlations between measurement error and gas meter type, years in operation and flow dialer reading are given. Error measurement is also expressed as amount of natural gas delivered to end users.

Keywords: gas meter; measurement error

Utjecaj mjerne pogreške plinomjera na obračun potrošnje plina

Prethodno priopćenje

Prirodni plin postao je jedan od važnijih energenata modernog doba. Plinovodni sustavi dovode plin od nalazišta krajnjim korisnicima, a mjerila protoka i njihova točnost važni su čimbenici tih sustava. U radu su dani rezultati eksperimentalno određenih mjernih pogrešaka mjerila s mjehovima veličine G4 dva različita proizvođača. Mjerila za ispitivanje odabrana su iz čitavog ovjernog razdoblja. Statističkom obradom analiziran je utjecaj tipa mjerila, starosti mjerila, stanja brojčanika te ispitnih protoka na mjernu pogrešku. Ispitivanjem je utvrđeno da iznos mjerne pogreške ovisi o tipu plinomjera. U zaključku su prikazani ekonomski pokazatelji mjerne pogreške na obračunate količine isporučenog prirodnog plina.

Ključne riječi: mjerna pogreška; plinomjer

\section{Introduction}

Natural gas is delivered from exploatation fields to end users through transport and distribution system consisting of complex network, underground storages, reduction and measurement-reduction stations [1]. At each point where natural gas is exchanged between different system operators as well as at the point where natural gas is delivered to end users accurate measurment of flow has to be done. Depending on pressure level it is fulfilled by turbine, rotary, ultrasonic and membrane measuring devices called flow meters. These instruments and measurements must meet certain standards i.e. must be certified (Measurement Instrument Directive, MID, MI-002) [2]. For the measurement of natural gas consumption in households, in last several decades, membrane gas meters sized G4 are being used.

In the experimental part of this study an examination of 240 membrane gas meters G4 was performed regarding their measurement error depending on various factors. Deatiled procedure will be explaained in the following chapter.

\section{Description of measuring equipment and samples}

The testing of samples was carried out in HEP-ODS d.o.o. in Osijek at an authorized laboratory numbered O.S.396. For this purpose, a testing rig BPG-R SONICAL SN G4; manufactured by "Actaris contadores calibration equipment division", Spain was used (Fig. 1). The device uses a system of critical nozzles as a reference flow meter. Each critical nozzle must meet the condition that the flow rates, determined after testing the nozzles, must not deviate by more than $\pm 0,5 \%$ from the average value of the flow for that nozzle [3].

As test fluid air is used. It is sucked through the tested gas meters and the critical nozzles by using a vacuum pump. During laboratory testing, the test rig [5] achieves the required flow rates from $Q_{\min }$ to $Q_{\max }$, and performs comparison of the volume measured by the gas meter and the volume of applied referential system of critical nozzles. G4 gas meters operate in wide range of flows, usual for housholds' consumption. Measuring accuracy of G4 gas meter has to be satisfied in the whole operating range.

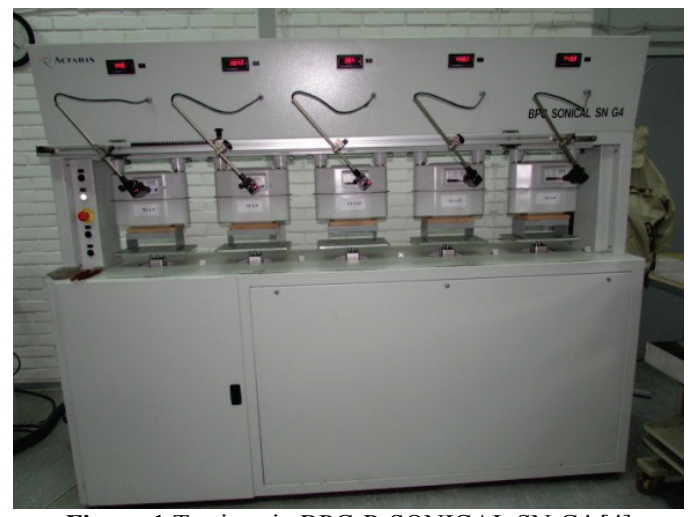

Figure 1 Testing rig BPG-R SONICAL SN G4 [4]

Taking into consideration the data on temperature and pressure at the tested gas meters and referent system, a measurement error of the gas meter and the associated measuring equipment is being calculated [6]. Establishing enough pressure drop through the nozzle leads to the formation of critical flow conditions in the throat of the nozzle. Critical conditions mean that the air velocity through the throat of the nozzle is equal to the speed of sound resulting in flow choke. That means maximum mass flow is achieved for the given input conditions, and cannot be increasd regardless of further increase in pressure drop through the nozzle [3].

Critical nozzles are located underneath the measuring table, and are located in a matrix of 6 nozzles in one block 
(Fig. 2). The required flow is achieved through a single nozzle or a flow combination of more nozzles. Technology of critical nozzles allows the reproducibility of the measurement results through a long period.

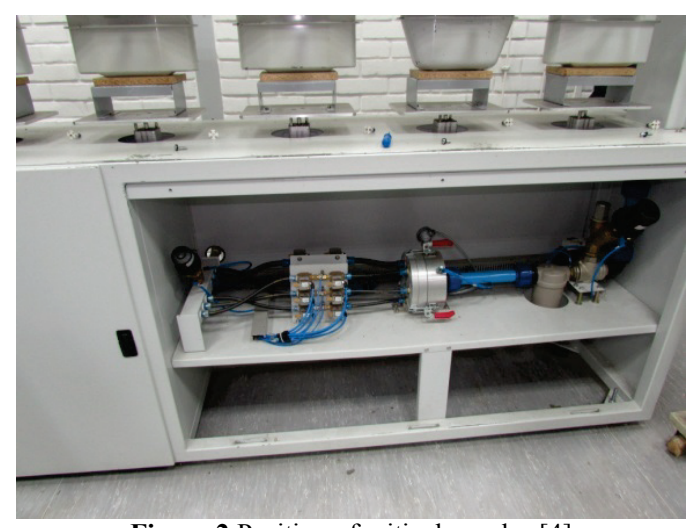

Figure 2 Position of critical nozzles [4]

Table 1 Distribution of samples for testing TYPE 1

\begin{tabular}{|c|c|c|c|}
\hline Ordinal Nr. & Group 1-Type 1 & Label & Quantity \\
\hline 1. & Subgroup 1 & T1-1 & 15 \\
\hline 2. & Subgroup 1 & T1-2 & 15 \\
\hline 3. & Subgroup 1 & T1-3 & 15 \\
\hline 4. & Subgroup 1 & T1-4 & 15 \\
\hline 5. & Subgroup 1 & T1-5 & 15 \\
\hline 6. & Subgroup 1 & T1-6 & 15 \\
\hline 7. & Subgroup 1 & T1-7 & 15 \\
\hline 8. & Subgroup 1 & T1-8 & 15 \\
\hline \multicolumn{3}{|l}{} & 120 \\
\hline
\end{tabular}

Table 2 Distribution of samples for testing TYPE 2

\begin{tabular}{|c|c|c|c|}
\hline Ordinal Nr. & Group 2-Type 2 & Label & Quantity \\
\hline 1. & Subgroup 2 & T2-1 & 15 \\
\hline 2. & Subgroup 2 & T2-2 & 15 \\
\hline 3. & Subgroup 2 & T2-3 & 15 \\
\hline 4. & Subgroup 2 & T2-4 & 15 \\
\hline 5. & Subgroup 2 & T2-5 & 15 \\
\hline 6. & Subgroup 2 & T2-6 & 15 \\
\hline 7. & Subgroup 2 & T2-7 & 15 \\
\hline 8. & Subgroup 2 & T2-8 & 15 \\
\hline \multicolumn{4}{|l}{} \\
\cline { 2 - 4 }
\end{tabular}

Gas meters size G4 from two manufacturers of measurement equipment mostly present on the Croatian market have been chosen for the testing. All gas meters selected were in use at households' regulation-measuring stations in the City of Osijek. The criteria for selection of the samples were: manufacturer of gas meters and the number of years that the selected gas meter spent in exploitation. A total of 240 samples were collected and divided into two equal groups according to manufacturers of gas meters. Then, each group is divided into eight subgroups of 15 samples (Tab. 1 and Tab. 2) according to years of operation of the sampled gas meter, for instance first subgroup was a year in operation, the second subgroup was two years in operation etc. up to eight years of operation, the verification period for a membrane type gas meter size G4.

The calibration protocol located within the software SONICAL demands defining of flow rates in which the measurement error of the gas meter will be examined. According to standards [8] the G4 membrane gas meters are usually tested in three values of flow: $Q_{1}=Q_{\text {min }}=40$ $\mathrm{l} / \mathrm{h}, \mathrm{Q}_{2}=0,2 \mathrm{Q}_{\max }=1200 \mathrm{l} / \mathrm{h}$ i $Q_{3}=Q_{\max }=6000 \mathrm{l} / \mathrm{h}$.

In order to get a better coverage of the entire measurement range of the gas meter, five characteristic points of flow are defined:

1) $Q_{1}=0,04 \mathrm{~m}^{3} / \mathrm{h}(40 \mathrm{l} / \mathrm{h})$ which is the minimum flow rate that can be registered by the gas meter sized G4;

2) $Q_{2}=1,2 \mathrm{~m}^{3} / \mathrm{h}(1200 \mathrm{l} / \mathrm{h})$;

3) $Q_{3}=2 \mathrm{~m}^{3} / \mathrm{h}(2000 \mathrm{l} / \mathrm{h})$;

4) $Q_{4}=4 \mathrm{~m}^{3} / \mathrm{h}(4000 \mathrm{l} / \mathrm{h})$;

5) $Q_{5}=6 \mathrm{~m}^{3} / \mathrm{h}(6000 \mathrm{l} / \mathrm{h})$ the maximum flow rate that the size $\mathrm{G} 4$ gas meter can register.

After that measurement error test can start.

\section{Sample testing}

By running a defined measurement protocol the measuring error testing procedure of the gas meter begins from the highest flow rate downward to the lowest flow rate as defined in previous chapter. After each of the defined flows, the program records the measurement results into the chart shown as screenshot in Fig. 3.

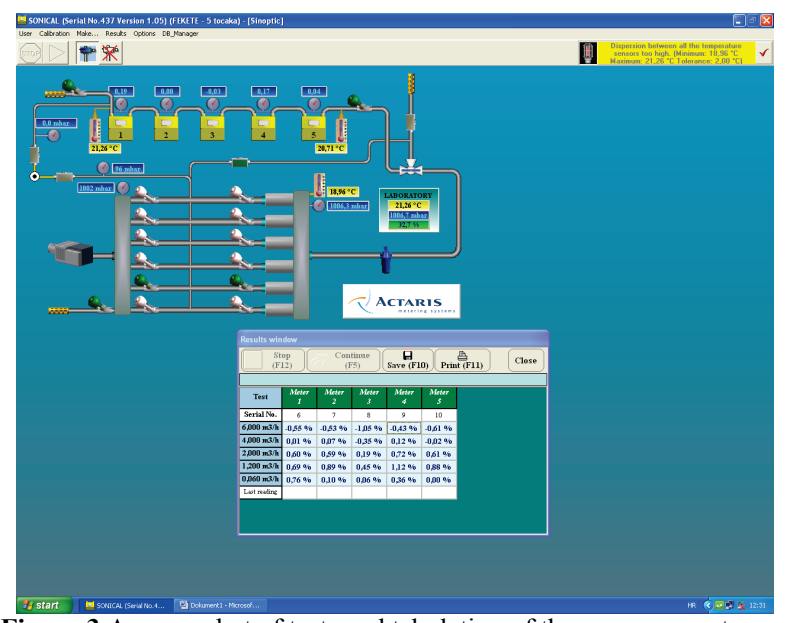

Figure 3 A screenshot of tests and tabulation of the measurement error [4]

The results of testing measurement error for each gas meter from one subgroup are filled in the chart. There are eight of these charts for each type of gas meter. Example for one set of values is given in Tab. 3 .

\section{Analysis of test results}

The program tool StatSoft Statistica version 12.5. is used to process the data. The input variables are: Type of the gas meter, Age, Condition of the dial and the Flow. The output variable is the Error (measurement error of the gas meter). First, descriptive statistics will be applied to describe the characteristics of the observed variables. After that, correlation between measurement error and output variables i.e. the type of the gas meter, the age of the gas meter, condition of the dial and the flow as input variables is examined.

Mentioned testings are first carried out on a complete sample which encompasses gas meters (TYPE 1 and TYPE 2), and then separately for the group of samples of TYPE 1 and TYPE 2 respectively. 
Table 3 The test results and data on selected sample

\begin{tabular}{|c|c|c|c|c|c|c|c|c|}
\hline \multicolumn{4}{|c}{ Type 1-Table 1, year of calibration 2013. } & \multicolumn{4}{c|}{ Test flows (1/h) } \\
\hline $\begin{array}{c}\text { Ordinal } \\
\text { Nr. }\end{array}$ & $\begin{array}{c}\text { Identification } \\
\text { of the sample }\end{array}$ & Serial number & $\begin{array}{c}\text { Condition of the } \\
\text { dial }\left(\mathrm{m}^{3}\right)\end{array}$ & 60 & 1200 & 2000 & 4000 & 6000 \\
\hline 1 & T1-1-1 & 30621825 & 02218 & $-2,55$ & $-0,79$ & $-0,97$ & $-1,57$ & $-1,78$ \\
\hline 2 & T1-1-2 & 30623676 & 00690 & $-1,49$ & $-0,73$ & $-0,64$ & $-0,37$ & $-0,75$ \\
\hline 3 & T1-1-3 & 30620493 & 00165 & $-1,56$ & $-1,34$ & $-1,13$ & $-1,48$ & $-0,86$ \\
\hline 4 & T1-1-4 & 30915073 & 00530 & $-1,64$ & $-0,66$ & $-0,86$ & $-1,19$ & $-1,55$ \\
\hline 5 & T1-1-5 & 30620497 & 00087 & $-1,09$ & $-0,65$ & $-0,85$ & $-1,19$ & $-0,88$ \\
\hline 6 & T1-1-6 & 30915798 & 01466 & $-1,85$ & $-0,78$ & $-0,77$ & $-1,10$ & $-1,45$ \\
\hline 7 & T1-1-7 & 30915797 & 01287 & $-2,19$ & $-1,12$ & $-1,04$ & $-1,09$ & $-1,62$ \\
\hline 8 & T1-1-8 & 30915796 & 01304 & $-1,10$ & $-1,28$ & $-1,05$ & $-1,29$ & $-1,83$ \\
\hline 9 & T1-1-9 & 30915802 & 01251 & $-2,49$ & $-1,84$ & $-2,10$ & $-2,34$ & $-2,58$ \\
\hline 10 & T1-1-10 & 30624133 & 01481 & $-2,48$ & $-0,47$ & $-0,70$ & $-0,74$ & $-0,53$ \\
\hline 11 & $\mathrm{~T} 1-1-11$ & 30915812 & 00892 & $-2,43$ & $-1,68$ & $-1,72$ & $-1,95$ & $-2,75$ \\
\hline 12 & $\mathrm{~T} 1-1-12$ & 30623698 & 00888 & $-1,73$ & $-0,33$ & $-0,59$ & $-0,54$ & $-0,64$ \\
\hline 13 & $\mathrm{~T} 1-1-13$ & 30621574 & 02873 & $-2,63$ & $-1,20$ & $-1,07$ & $-0,95$ & $-1,39$ \\
\hline 14 & $\mathrm{~T} 1-1-14$ & 30623660 & 00888 & $-0,62$ & 0,52 & 0,02 & $-0,30$ & $-0,59$ \\
\hline 15 & $\mathrm{~T} 1-1-15$ & 30915074 & 00589 & $-1,93$ & $-0,68$ & $-0,52$ & $-1,27$ & $-1,64$ \\
\hline
\end{tabular}

\subsection{Results of sample testing for both types of gas meters}

Descriptive statistics is applied to analyse characteristics of the observed variables for samples of both types of gas meters (Tab. 4).

For continuous variables: arithmetic mean value $(\mu)$, minimum ( $\min$ ) and maximum ( $\max$ ) value and finally standard deviation $(\sigma)$ are calculated. The only category variable is gas meter type for which frequency (number) and percentage (\%) are given.

Table 4 Descriptive statistics of the analysed variables for both types of

\begin{tabular}{|c|c|c|c|c|}
\hline $\begin{array}{c}\text { Ord. } \\
\text { nr. }\end{array}$ & $\begin{array}{c}\text { Variable } \\
\text { name }\end{array}$ & $\begin{array}{c}\text { Variable } \\
\text { description }\end{array}$ & $\begin{array}{c}\text { Variable } \\
\text { type }\end{array}$ & $\begin{array}{c}\text { Descriptive } \\
\text { statistics } \\
\end{array}$ \\
\hline 1 & $\begin{array}{l}\text { Type of the } \\
\text { gas meter }\end{array}$ & $\begin{array}{l}\text { Type of the } \\
\text { gas meter }\end{array}$ & $\begin{array}{c}\text { Categorical } \\
\text { numerical } \\
\text { variable } \\
\end{array}$ & $\begin{array}{l}1=600(50 \%) \\
2=600(50 \%)\end{array}$ \\
\hline 2 & Age & $\begin{array}{l}\text { Age of the } \\
\text { device, i.e. the } \\
\text { number of } \\
\text { years after } \\
\text { calibration }\end{array}$ & $\begin{array}{c}\text { Continuous } \\
\text { numeric } \\
\text { variable }\end{array}$ & $\begin{array}{c}\mu=4,5 \\
\min =1 \\
\max =8 \\
\sigma=2,2922\end{array}$ \\
\hline 3 & $\begin{array}{l}\text { Condition } \\
\text { of the dial }\end{array}$ & $\begin{array}{l}\text { Condition of } \\
\text { the dial }\left[\mathrm{m}^{3}\right]\end{array}$ & $\begin{array}{c}\text { Continuous } \\
\text { numeric } \\
\text { variable }\end{array}$ & $\begin{array}{c}\mu=6163,338 \\
\min =87 \\
\max =23847 \\
\sigma=5034,351 \\
\end{array}$ \\
\hline 4 & Flow & Gas flow / 1/h & $\begin{array}{c}\text { discrete } \\
\text { numeric } \\
\text { variable, } \\
\text { value: } 60, \\
1200,2000, \\
4000,6000\end{array}$ & $\begin{array}{c}60=120(20 \%) \\
1200=120(20 \%) \\
2000=120(20 \%) \\
4000=120(20 \%) \\
6000=120(20 \%) \\
\mu=2652,00 \\
\sigma=2111,713\end{array}$ \\
\hline 5 & $\begin{array}{c}\text { Error } \\
\text { (output } \\
\text { variable) }\end{array}$ & $\begin{array}{c}\text { Error in the } \\
\text { measured gas } \\
\text { consumption / } \\
\%\end{array}$ & $\begin{array}{c}\text { Continuous } \\
\text { numeric } \\
\text { variable }\end{array}$ & $\begin{array}{c}\mu=-0,150183 \\
\min =-6,83 \\
\max =3,17 \\
\sigma=1,042\end{array}$ \\
\hline
\end{tabular}

Box-Whiskers diagram (Fig. 4.) shows the arithmetic mean value for the variable "error" (line 5, Tab. 4.) based on samples of both types of gas meters. The confidence range in result of testing is at the level of $68 \%$. That means the error value of entire tested sample is in range between $-1,19$ and 0,89 with probability of $68 \%$. Similarly, the confidence interval at the probability level $95 \%$ guarantees that the measurement error will occur in the range between $-2,19$ and 1,89 . Higher probability range narrower confidence range.

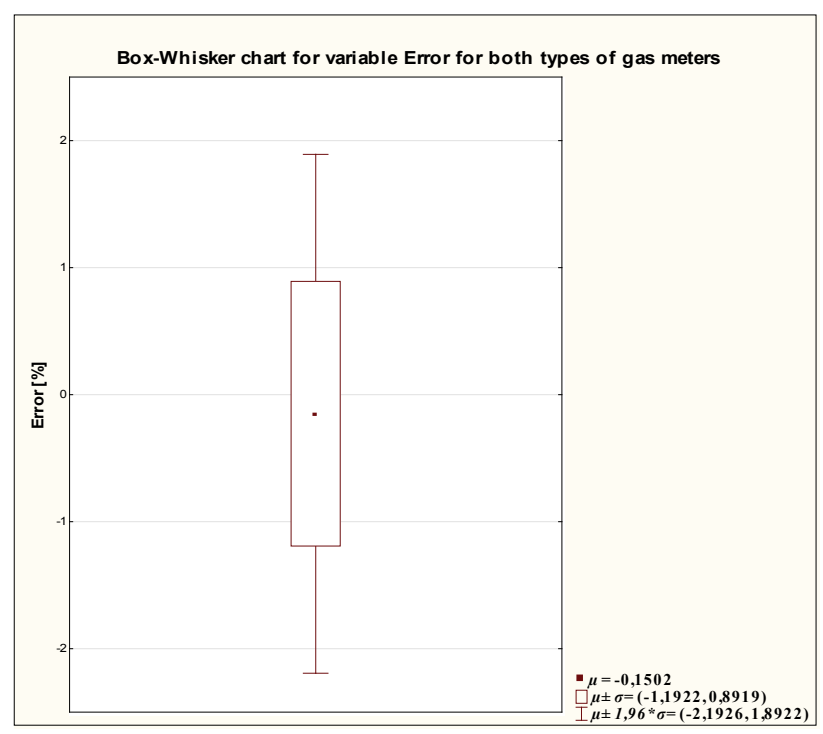

Figure 4 Box-Whisker's graph for the variable Error for both types of gas meters

In order to check the correlation between measurement error and type of the gas meter, t-test [9] for independent samples of gas meters is made. The purpose of the test is to examine the hypothesis that mean value of error by both gas meters types is equal.

Table 5 t-test result- dependence of mean values for gas meters type 1 and type 2

\begin{tabular}{|c|c|c|c|c|c|c|}
\hline \multirow{2}{*}{ Variable } & \multicolumn{6}{|c|}{ T-tests,dependence ofmean values for both type of } \\
\cline { 2 - 7 } & $\begin{array}{c}\text { Mean } \\
1\end{array}$ & $\begin{array}{c}\text { Mean } \\
2\end{array}$ & $\begin{array}{c}\mathrm{t} \\
\text { value }\end{array}$ & $\mathrm{df}$ & $\mathrm{p}$ & \\
\hline Error & $-0,25$ & $-0,048$ & $-3,4159$ & 1198 & 0,00066 & \\
\hline Variable & $\begin{array}{c}\text { Valid } \\
\mathrm{N}\end{array}$ & $\begin{array}{c}\text { Valid } \\
\mathrm{N}\end{array}$ & $\begin{array}{c}\text { Std.Dev } \\
1\end{array}$ & $\begin{array}{c}\text { Std.Dev. } \\
2\end{array}$ & $\begin{array}{c}\text { F-ratio } \\
\text { Variance }\end{array}$ & $\begin{array}{c}\mathrm{p} \\
\text { Variance }\end{array}$ \\
\hline Error & 600 & 600 & 1,2793 & 0,7184 & 3,17127 & 0 \\
\hline
\end{tabular}


Nevertheless, t-test has shown that there is a significant statistical difference between the mean values of errors at type 1 gas meters and the gas meter Type 2 ( $p$ $<0,05)$. The results are given in Tab. 5 .

Box-Whisker diagram (Fig. 5) shows the mean and standard errors for type 1 and type 2 gas meters respectively.

Testing of correlation between the error and the type of gas meter refers to conclusion that gas meter type affects the value of a measurement error significantly. The mean value error by type 2 gas meter is smaller in absolute value. It can be concluded that the measurement errors are significantly smaller and there is also a narrower confidence interval which means greater security in the expected mean value i.e. better reliability in practice.

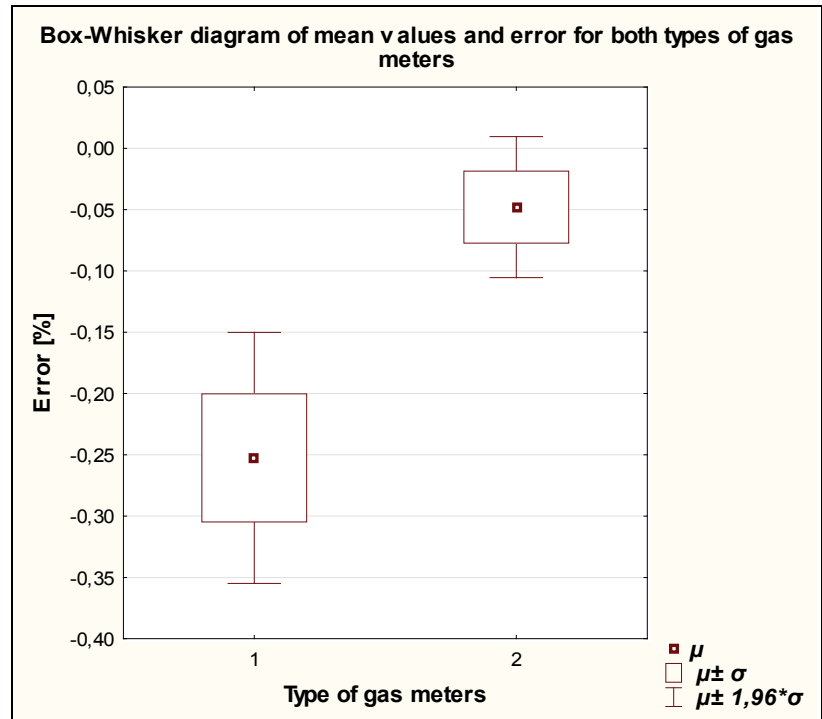

Figure 5 Box-Whisker diagram of the mean values and Error for both types of gas meters

Testing the dependence of error and other variables has shown weak linear correlation between measurement error and age of the gas meter, condition of the dial and flow.

Table 6 Descriptive statistics of the observed variables for gas meters

\begin{tabular}{|c|c|c|c|c|}
\hline $\begin{array}{c}\text { Ord. } \\
\text { nr. }\end{array}$ & $\begin{array}{l}\text { Variable } \\
\text { Name }\end{array}$ & $\begin{array}{c}\text { Variable } \\
\text { Description }\end{array}$ & $\begin{array}{c}\text { Variable } \\
\text { Type }\end{array}$ & $\begin{array}{c}\text { Descriptive } \\
\text { statistics }\end{array}$ \\
\hline 1 & Age & $\begin{array}{l}\text { Age of the } \\
\text { device, i.e. the } \\
\text { number of } \\
\text { years after } \\
\text { calibration }\end{array}$ & $\begin{array}{c}\text { Continuous } \\
\text { numeric } \\
\text { variable }\end{array}$ & $\begin{array}{c}\mu=4,5 \\
\min =1 \\
\max =8 \\
\sigma=2,2932\end{array}$ \\
\hline 2 & $\begin{array}{l}\text { Condition } \\
\text { of the dial }\end{array}$ & $\begin{array}{l}\text { Condition of } \\
\text { the dial }\left(\mathrm{m}^{3}\right)\end{array}$ & $\begin{array}{l}\text { Continuous } \\
\text { numeric } \\
\text { variable }\end{array}$ & $\begin{array}{c}\mu=5764,792 \\
\min =87 \\
\max =23789 \\
\sigma=4667,360\end{array}$ \\
\hline 3 & Flow & Gas flow $(1 / h)$ & $\begin{array}{c}\text { discrete } \\
\text { numeric } \\
\text { variable, } \\
\text { value: } 60, \\
1200,2000 \text {, } \\
4000,6000\end{array}$ & $\begin{array}{c}60=120(20 \%) \\
1200=120(20 \%) \\
2000=120(20 \%) \\
4000=120(20 \%) \\
6000=120(20 \%) \\
\mu=2652 \\
\sigma=2112,594\end{array}$ \\
\hline 4 & $\begin{array}{c}\text { Error } \\
\text { (output } \\
\text { variable) }\end{array}$ & $\begin{array}{c}\text { Error in the } \\
\text { measured gas } \\
\text { consumption } \\
(\%)\end{array}$ & $\begin{array}{l}\text { Continuous } \\
\text { numeric } \\
\text { variable }\end{array}$ & $\begin{array}{c}\mu=-0,252483 \\
\min =-6,83 \\
\max =3,17 \\
\sigma=1,2792\end{array}$ \\
\hline
\end{tabular}

\subsection{Results of testing type 1 sample}

Descriptive statistics is used to describe characteristics of the observed variables for samples of the type 1 gas meter (Tab. 6).

By continuous variables were observed: arithmetic mean $(\mu)$, minimum $(\min )$, maximum $(\max )$ and standard deviation $(\sigma)$.

Fig. 6 shows that increase in age leads to a certain increase in the measurement error, which can be approximated by a specific linear trend, but at the same time declinations from this trend can be noticed. Also, by newer devices (between $1 \div 4$ years old) error tends to negative values, by 5 years old devices mean value error is about 0 , while by older devices (aged $6 \div 8$ years) mean value error tends to positive values.

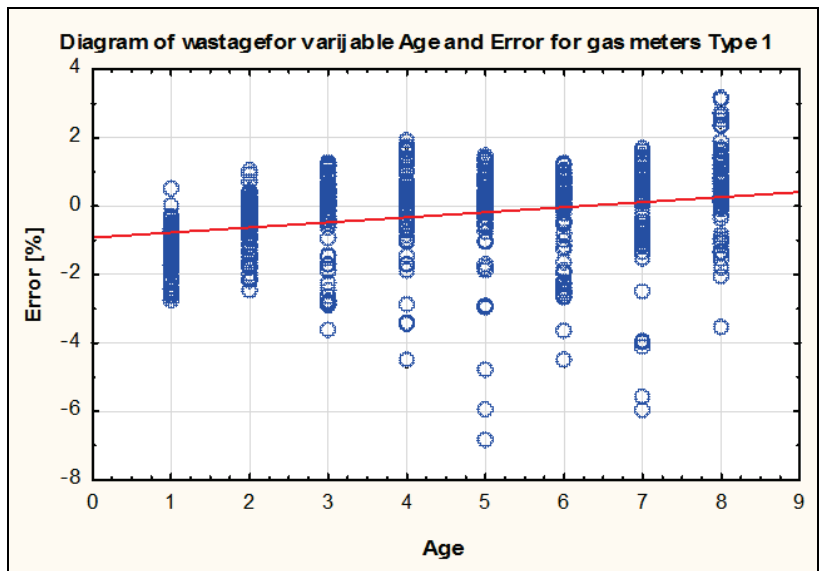

Figure 6 Diagram of the variables Age and Error for gas meters TYPE1

T-test has shown no significant statistical difference in gas meter error at different ages. Comparing the dependence of error on the condition of the dial it can be seen that the error is generally in the range $[-2,2]$ whilst the value of dial lies between 0 and $10000 \mathrm{~m}^{3}$.

Comparing variable errors and flow it is evident that at minimum flow errors are mostly in the negative territory, while at higher flows errors have more positive values.

Finally, the following can be concluded [10]:

- there is a weak positive linear connection between the gas meter age and error. Also, various age of gas meter does not affect error,

- there is a weak positive linear connection between the condition of the dial and error and flow and error. Also, various flow readings do not affect error significantly.

\subsection{Results of testing type 2 sample}

Descriptive statistics is used to describe characteristics of the observed variables for samples of the type 2 gas meter.

By continuous variables were observed: arithmetic mean $(\mu)$, minimum $(\min )$, maximum $(\max )$ and standard deviation $(\sigma)$.

Fig. 7 shows the linear graph of variable value Error of the studied sample for type 2 gas meters in 600 test points. The diagram shows that the majority of values varies between -1 and $+1 \%$, it also shows slightly few extreme deviations in the negative values up to $-4,17 \%$ 
and in the positive values up to $+2,41 \%$. The arithmetic mean value in this sample is $-0,048$.

By testing correlation between error and age it can be concluded that by the newer gas meters the deviations tend to negative values while by gas meters sampled from second half of the verification period deviations tend to be in the positive values. T-test has shown that there is a statistically significant difference between error and age of gas meters.

Table 7 Descriptive statistics of the observed variables for gas meters TYPE 2

\begin{tabular}{|c|c|c|c|c|}
\hline $\begin{array}{l}\text { Ord. } \\
\text { nr. }\end{array}$ & $\begin{array}{l}\text { Variable } \\
\text { Name }\end{array}$ & $\begin{array}{c}\text { Variable } \\
\text { Description }\end{array}$ & $\begin{array}{c}\text { Variable } \\
\text { Type }\end{array}$ & $\begin{array}{c}\text { Descriptive } \\
\text { statistics }\end{array}$ \\
\hline 1 & Age & $\begin{array}{l}\text { Age of the } \\
\text { device, i.e. the } \\
\text { number of } \\
\text { years after } \\
\text { calibration }\end{array}$ & $\begin{array}{l}\text { Continuous } \\
\text { numeric } \\
\text { variable }\end{array}$ & $\begin{array}{c}\mu=4,5 \\
\min =1 \\
\max =8 \\
\sigma=2,2932\end{array}$ \\
\hline 2 & $\begin{array}{l}\text { Condition } \\
\text { of the dial }\end{array}$ & $\begin{array}{l}\text { Condition of } \\
\text { the dial }\left(\mathrm{m}^{3}\right)\end{array}$ & $\begin{array}{l}\text { Continuous } \\
\text { numeric } \\
\text { variable }\end{array}$ & $\begin{array}{c}\mu=6561,883 \\
\min =134 \\
\max =28470 \\
\sigma=5350,629\end{array}$ \\
\hline 3 & Flow & Gas flow $(1 / h)$ & $\begin{array}{c}\text { discrete } \\
\text { numeric } \\
\text { variable, } \\
\text { value: } 60 \text {, } \\
1200,2000 \text {, } \\
4000,6000\end{array}$ & $\begin{array}{c}60=120(20 \%) \\
1200=120(20 \%) \\
2000=120(20 \%) \\
4000=120(20 \%) \\
6000=120(20 \%) \\
\mu=2652,00 \\
\sigma=2112,594\end{array}$ \\
\hline 4 & $\begin{array}{c}\text { Error } \\
\text { (output } \\
\text { variable) }\end{array}$ & $\begin{array}{l}\text { Error in the } \\
\text { measured gas } \\
\text { consumption } \\
(\%) \\
\end{array}$ & $\begin{array}{l}\text { Continuous } \\
\text { numeric } \\
\text { variable }\end{array}$ & $\begin{array}{c}\mu=-0,047883 \\
\min =-4,17 \\
\max =2,41 \\
\sigma=0,718366\end{array}$ \\
\hline
\end{tabular}

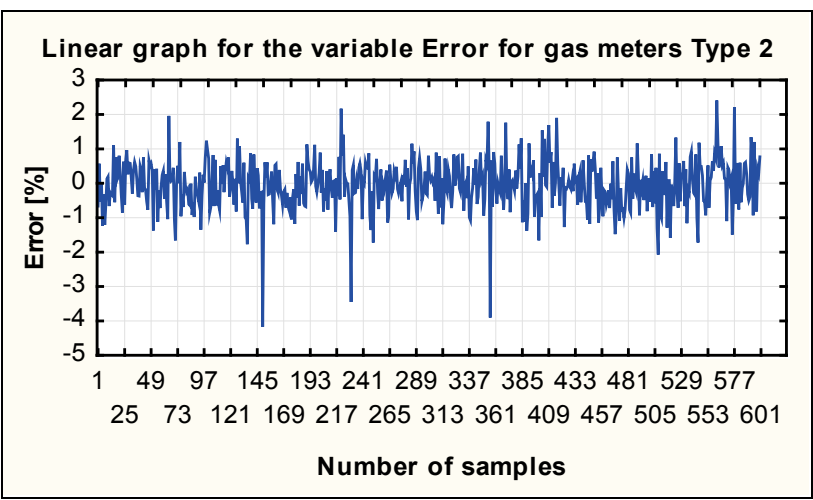

Figure 7 Linear graph for the variable Error for gas meters TYPE 2

Comparing dependence errors and condition of the dial it is evident that in the range from 0 to $5000 \mathrm{~m}^{3}$ the measurement errors are evenly distributed in the positive and negative range, while in the area of 5000 to $20000 \mathrm{~m}^{3}$ there are more positive errors.

Comparing variables error and flow, it is evident that most of the errors are in the range of -2 to $2 \%$ and that there is a slight increase in errors with an increase in flow. With the minimum flow $(60 \mathrm{l} / \mathrm{h})$ there is the most negative value measurement. T-test has shown that there is a statistically significant difference between the errors at different flow rates.

From the above it can be concluded [10]:

- there is a weak positive linear connection between the gas meter's age and error. Also, age of gas meter does affect error significantly,

- there is a weak positive linear connection between the dial reading and error, there is a weak negative linear connection between the flow and error, and the errors by different flows differ remarkably.

\section{Conclusion}

Taking into account that the arithmetic mean value is the mean error value of measurement of the selected gas meter type, during eight previous years of operation between two calibrations, measurement error can be expressed to the amount of supplied natural gas.

Analysis of variance showed that there is a significant difference between the errors in Type 1 gas meter and gas meter Type $2(F=11,67, p<0,05)$. Mean value of errors by type 2 device is smaller in absolute value resulting in significantly lower measurement errors. Type of gas meter significantly affects the value of the resulting measurement error.

The absolute value of error in gas meter type 2 is less than the absolute value of error in gas meter type 1 , but also confidence interval in the error is lower, by gas meters type 2 is at the level of $95 \%$, which means that with a $95 \%$ certainty it can be asserted that the error at gas meter type 2 will be between $-0,11$ and 0,01 . With gas meter type 1 the confidence interval is wider, meaning that with $95 \%$ probability mean value of error is going to be between $-0,36$ and $-0,15$. In practice, it is more reliable to have a lower confidence interval, since it means more security in the expected mean value. The conclusion is that expected mean value is more certain at gas meter Type 2, making it more suitable for use.

Based on annual consumption of natural gas for the household category for each calendar year from 2006 to 2013 and according to the types of membrane gas meters used and total annual consumption from all the meters throughout the distribution area of HEP-Plin, table 8. shows that TYPE 1 gas meters, with total annual consumption over 8 years of $231834275 \mathrm{~m}^{3}$, contribute in the total annual consumption of all gas meters with 19,27 \%, and gas meters TYPE 2, with total annual consumption over 8 years of $209246056 \mathrm{~m}^{3}$, with only $17,39 \%$. The share of natural gas to be delivered to consumers in the category of household through gas meters TYPE 1 and TYPE 2 together in relation to the total amount of gas for all gas related meters is $36,67 \%$.

Tab. 8 also shows the results of the average errors (the arithmetic mean of all the errors measured on samples for the selected type of gas meter) obtained with the descriptive statistics of the output variable Error. For type 1 gas meters the average error is $-0,25 \%$. If we know that in eight years through that gas meter passed a total of more than 230 million $\mathrm{m}^{3}$, then the average error is $-585342 \mathrm{~m}^{3}$ that equals to approximately $€-292671$.

If we consider the average interval errors $[-0,36$; $-0,15$ ] obtained by analyzing the variance at the level of confidence of $95 \%$, then the error gas meter type 1 ranges from -834603 to $-347301 \mathrm{~m}^{3}$ or from -417301 to $-173875 €$. Practically, that represents loss for the distributor of natural gas, not being invoiced to customers through the verification period of 8 years compared to the ideal measurement.

Following the same logic for gas meters type 2 the average error is $-0,048 \%$, the amount of gas supplied via 
this type of gas meter is more than 209 million $\mathrm{m}^{3}$, that is $-100193 \mathrm{~m}^{3}$ that equals approximately the amount of $€$ -50096 .

Table 8 The average measurement error through eight years

\begin{tabular}{|c|c|c|}
\hline Consumption over the gas & TYPE 1 & TYPE 2 \\
\cline { 2 - 3 } meters in 8 years $\left(\mathrm{m}^{3}\right)$ & 231834275 & 209246056 \\
\hline $\begin{array}{c}\text { Average error } \\
\text { (arithmetic mean) }(\%)\end{array}$ & $-0,252483$ & $-0,047883$ \\
\hline Overall average error $\left(\mathrm{m}^{3}\right)$ & $-585342,13$ & $-100193,29$ \\
\hline $\begin{array}{c}\text { Overall average error } \\
€\left(0,5 € / \mathrm{m}^{3}\right)\end{array}$ & $-292671,07$ & $-50096,64$ \\
\hline $\begin{array}{c}\text { Interval of average error } \\
(p<0,05)(\%)\end{array}$ & $-0,36$ & $-0,11$ \\
\hline $\begin{array}{c}\text { Interval of average error } \\
(p<0,05)\left(\mathrm{m}^{3}\right)\end{array}$ & $-834.603,39$ & $-230170,66$ \\
\cline { 2 - 3 } & $-347751,41$ & 20924,61 \\
\hline $\begin{array}{c}\text { Interval of average error } \\
(p<0,05)(€)\end{array}$ & $-417301,69$ & $-115085,33$ \\
\cline { 2 - 3 } & $-173875,71$ & 10462,30 \\
\hline
\end{tabular}

Including interval of the average error for gas meters type $2[-0,11 ; 0,01]$ based on analysis of variance at the confidence level of $95 \%$, gas meter error varies between -230170 and $20924 \mathrm{~m}^{3}$ that equals from -115085 up to $10462 €$.

Thorough analysis of two types of gas meters pointed out that gas meter type 2 has less error, is more accurate than gas meter type 1 . That enables the gas supplied to consumers to be invoiced more precisely.

\section{$6 \quad$ Literature}

[1] Ficco, G.; Dell'Isola, M.; Vigo, P.; Celenza, L. Uncertainty analysis of energy measurements in natural gas transmission. // Flow Measurement and Instrumentation. 42, 4(2015), $\quad$ pp. $58-68 \quad$ DOl: 10.1016/j.flowmeasinst.2015.01.006

[2] State Office for Metrology, Regulation on technical and metrological requirements related to measuring instruments. // Narodne novine 85(2013)

[3] State Office for Metrology and Croatian Standards Institute: Ordinance on the metrological requirements for equipment for the testing of gas meters. // Narodne novine 137(2003)

[4] Personal images and drawings archive of the author of the paper, Osijek, 2014.

[5] Pavlović, B. The development of a standard measurement system for small flows of gas. // Ph.D. Thesis, Zagreb, 2010.

[6] Oosthuizen, P. O.; Carscalen, W. E. Compressible Fluid Flow, Mc Graw Hill, New York, 1997.

[7] Fancev, M. Fluid mechanics. // Separat of tehnical encyclopedia No. 8, JLZ, Zagreb, 1982.

[8] State Office for Metrology and Croatian Standards Institute: Ordinance on the metrological requirements related to flow measurements of the gas volume. // Narodne novine 53(2002).

[9] Pavlić, I. Statistical theory and application. Tehnička knjiga Zagreb, 1988.

[10] Petz, B. Statistical methods for no mathematician. Naklada Slap. Zagreb, 2007.

\section{Authors' addresses}

\section{Zlatko Tonković}

Hep-Plin d.o.o.

Cara Hadrijana 7, 31000 Osijek, Croatia

E-mail: zlatko.tonkovic@hep.hr

Damir Fekete

HEP-Plin d.o.o.

Cara Hadrijana 7, 31000 Osijek, Croatia

E-mail: damir.fekete@hep.hr

Pero Raos

J. J. Strossmayer University of Osijek,

Faculty of Mechanical Engineering in Slavonski Brod,

Trg Ivane Brlić Mažuranić 2, 35000 Slavonski Brod, Croatia

E-mail: praos@sfsb.hr 